\title{
Relative Effectiveness of Peer Assessment Technique (PAT) in Enhancing Secondary School Students' Academic Achievement and Interest in Economics
}

\author{
Morrison, U. I. (Ph.D), Abanobi, C. C. (Ph.D), Ifemeni, A. L. \\ Department of Educational Foundations, Federal College of Education (Technical), Asaba, Nigeria
}

\begin{abstract}
Successful implementation of continuous assessment in schools depends on effective and efficient use of a variety of assessment techniques to determine students' learning outcomes. Among these various techniques are the peer assessment technique (PAT), teacher assessment technique (TAT) among others. This study examined relative effectiveness of PAT in enhancing secondary school students' academic achievement and interest in Economics. Six research questions and six null hypotheses guided the study. The study adopted a quasiexperimental research design. 1,750 SS II students in twelve (12) secondary schools in Delta North Education Zone (Ministry of Education, Exams and Standard, Asaba) comprised the population of the study. The sample of this study comprised 107 (49 males and 58 females) SSII students who offered Economics from two co-educational secondary schools in Oshimili South Local Government Area, Delta North Education Zone of Delta State. The instruments for data collection were Economics Achievement Test (EAT) and Economics Interest Inventory (EII). The EAT and EII were validated by subject specialists and measurement and evaluation experts. The reliability coefficients of EAT and EII were 0.95 and 0.81 respectively. Mean and standard deviation were used to answer the research questions. Analysis of Covariance (ANCOVA) was used to test the null hypotheses at 0.05 level of significance. The findings revealed among others that the mean achievement scores of students exposed to TAT is higher than that of those exposed to PAT and the difference in their mean achievement scores is significant. Students exposed to TAT have more interest than those exposed to PAT but the difference in their mean interest scores is not significant. Based on the findings, the study recommended among others that secondary school authorities should use only TAT for assessment of secondary school students' academic achievement in all secondary schools.
\end{abstract}

Keywords: Academic Achievement, Interest, Peer Assessment Technique, Teacher Assessment Technique, ,

\section{INTRODUCTION}

$\mathrm{T}$ he act of assessment seems to be as old as mankind because it is a tool used to evaluate performance and maintain standard using sets of criteria. Assessors set bench marks to judge the work of students in and out of the classroom. Assessment is an integral part of instruction as it determines whether or not the goals of education are being met. Assessment affects decisions about students' grades, placement, advancement and instructional needs. Edutopia (2014) has it that assessment inspires one to ask these hard questions: Are teachers teaching what is to be taught? Are students learning what they are supposed to learn? Is there a particular way to teach, thereby promoting better learning? Therefore, the role of assessment cannot be over-emphasized.

Assessment has been variously defined by different authors. In the view of Yambi (2018) assessment is the processes involve collecting data about a performance or work product; it is a related series of measures used to determine a complex attribute of an individual or group of individuals. This involves gathering and interpreting information about student level of attainment of learning goals Anikweze (2005) posits that assessment is the means of knowing what kind of learning that has taken place during learner's schooling and as such can be rightly regarded as a basic demand in school accountability. Khan (2019) and Nkwocha (2004) align that assessment involves the use of different instruments, strategies and sources to gather and record information about how much individual learners have developed in the three domains of learning at specific intervals while still under training. Assessment is an essential stock-taking aspect of the teaching-learning activity for the determination of learning outcome. Assessment is the process of gathering and discussing information from multiple and diverse sources in order to develop a deep understanding of what students know, understand, and can do with their knowledge as a result of their educational experiences (Ghaicha, 2016; Huba \& Freed, 2000). This makes it imperative, that for effective feedback in the teaching-learning process to take place, learners must be assessed. This means that proper assessment of students' learning outcome in the classrooms is very crucial in the teaching-learning process (Otubelu, 2008).

Edutopia (2014) put it that assessment is used in educational settings for a variety of purposes such as keeping track of learning, diagnosing reading and writing difficulties, determining eligibility for programmes, evaluating programmes, evaluating teaching and reporting to others. Underlying all these purposes is a basic concern for improving teaching and learning. Edutopia further stressed that today's students need to know not only the basic reading and arithmetic skills, but also skills that will allow them to face a world that is continually changing. They must be able to think critically, to analyze, and make inferences. If an educational 
assessment practice is to be considered valid, it must inform instruction and lead to improved teaching and learning.

In Nigeria, educational assessment is based on continuous assessment. The federal government stipulated this in the National Policy on Education that "educational assessment and evaluation will be liberalized by passing them whole or part on continuous assessment of the progress of the individual" (Federal Republic of Nigeria (FRN), 2004, p.9). This is emphasized by the Federal Republic of Nigeria (FRN,2013). The successful implementation of continuous assessment in schools as opined by Ghaicha (2016) and Agbaegbu in Eze (2006) depends on effective and efficient use of a variety of assessment techniques to determine students' learning outcomes. Among these various techniques are the peer assessment technique (PAT), teacher assessment technique (TAT) and some others. Peer Assessment Technique (PAT) generally involves peers assessing each others' work based on accepted rules or using instructional rubrics. PAT is unlike the Teacher Assessment Technique (TAT) in which a teacher gives out instructions and also evaluates students' success without involving students in the assessment process. There are different types of peer assessment. These are: peer assessment for staff (teacher evaluation) and peer assessment for student evaluation. This present study is concerned with the peer assessment for student evaluation.

Peer assessment technique (PAT) has been variously defined by many scholars. Explanations of PAT have been quite varied although evaluators generally agree that peerassessment involves one student assessment of the performance or success of another student. Khadijeh (2010) defines it as a student's evaluation of each other's performance. It is one form of innovative assessment, which aims to improve the quality of learning and empower learners, where traditional forms can by-pass learners' needs. Peerassessment may take place in pairs or groups, where the aim may be as much the development of group processes as the promotion or judgement of individual learning. Peer Assessment therefore, is a process whereby students assess assignments or tests of their peers based on teacher's benchmark or instructional rubrics (Sadler \& Eddie, 2006). Instructional rubrics are information feedback or scoring guides that are used by teachers and participants in assessing and evaluating students' work based on sets of criteria ranging from poor to excellent performance. The practice is employed to save teacher's time and improve students' understanding of course materials as well as improve students' thinking skills as students would be exposed to each other's work, learn different steps in presenting, analyzing, evaluating, and solving problems.

Peer Assessment is much more than students' marking their own or each other's work because it also helps students to learn from their peers' solved work. To improve learning, it must be an activity that engages students with the quality of their work and helps them reflect on how to improve on it.
Peer Assessment enables students to give each other valuable feedback so that they can learn from it and support each other (Chin, 2016; Ryan, Marshall, Porter, \& Jia, 2007). Peer assessment requires students to provide feedback or grades (or both) to their peers on a product, process, or performance, based on the criteria of excellence for that product or event which students may or may not be involved concomitantly in determining the criteria (Falchikov, 2005).

Ifeakor as cited by Eze (2006) noted that PAT unlike TAT is sparingly used by secondary school teachers. Some teachers, however, claim that they use PAT because they usually instruct students to exchange their books after completing classroom assignments/tests, the students then mark their assignments/tests using assessment criteria given by their teacher. It is a known fact that these teachers do this to reduce the burden of marking large number of students' classroom assignments/tests. These teachers do not use PAT for students' benefits but rather for their (teachers) benefits. Therefore, the infrequent use of peer assessment technique means that students are rarely involved in the assessment process. PAT is different from Teacher Assessment Technique (TAT) although it is the conventional method used by teachers in teaching/learning processes. Nevertheless, in TAT, students are seen as passive receivers of information in the classroom who are expected to provide samples of their knowledge in classroom tests designed by the teacher (Asuai $\&$ Adeleye, 2013). Teachers in TAT act as personnel who give out instructions and also as the judges who evaluate students' success. This process normally makes the students passive and not active because they only listen to instructions given to them by their teachers (Asuai \& Adeleye, 2013).

The assessment and mode of teaching in some of the secondary schools in Nigeria seem to be teacher assessment technique (TAT) which might not give the students the opportunity to be creative and independent in solving problems and assess one another in terms of their strengths and weaknesses. TAT does not give students the opportunity of being involved in evaluating their own learning. Students' involvement in their assessment could have positive effects on their achievement and interest in secondary school subjects like Economics. The level of both male and female students' achievement in some vital subjects as Economics has not been encouraging as expected. For instance, the Vanguard newspaper (August 11, 2014) reported that the West Africa Examination Council, (WAEC) has released its May/June 2014 West African Senior School Certificate Examination (WASSCE) results, recording mass failure in vital subjects. Also, the Sun newspaper (August 12, 2014) reported that for the fourth consecutive year, candidates who sat for the West African Examination Council (WAEC) May/June West African Senior School Certificate Examination (WASSCE) recorded mass failure. Only $31.28 \%$ obtained five credits including English and Mathematic. More so, Anayochi, Anagara, Anosike and Asoluka (2010) reported that the analysis of past NABTEB results of 2006, 2007 and 2008 
have shown that there have been continuous failures in vital subjects such as Mathematics, English language and Economics. They observed that the examination results in Mathematics, English language and Economics were poor and therefore was not encouraging. This has shown that the academic achievement of both male and female secondary school students in Economics is low.

The researcher felt that this continuous decline in the male and female secondary school students' academic achievement in Economics may partly be as a result of the traditional method of assessment which teachers employ in teaching and learning processes. With search for means of ameliorating the situation, PAT, may provide such means; hence the study's necessity.

\section{Statement of the Problem}

The use of only TAT for classroom testing may appear to have contributed to students' lack of interest and poor achievement in Economics in public examinations such as West African Examination Council (WAEC), National Examination Council (NECO) and National Business and Technical Examination Board (NABTEB) because some of the students hardly see each other's marked work which would have helped them to learn from and support each other to improve learning.

The use of peer assessment technique (PAT) in teaching and learning processes has contributed to excellent performance in Mathematics among secondary school students overseas (Andrade \& Du, 2005; Sadler \& Eddie, 2006; Schafer, Ben \& Newbery, 2001). In Nigeria, PAT is rarely used by secondary school teachers, nevertheless, some researchers have made efforts to explore the efficacy of PAT in some areas such as Geography, Chemistry, Mathematics, English Language, French Language and their findings revealed that PAT seem to have significant positive effects on students' achievement and interest in the areas investigated.

Limited research evidence exists of the effects of using PAT as a classroom assessment strategy to increase students' academic achievement and interest in Economics. Thus, the problem of this study is to find out how relatively effective PAT is in enhancing secondary school students' academic achievement and interest in Economics.

The following research questions guided the study:

1. What are the mean achievement scores of students exposed to PAT and that of those exposed to PAT in Economics?

2. What are the mean achievement scores of male and female students exposed to PAT in Economics?

3. What are the mean achievement scores of male and female students exposed to TAT in Economics?

4. What are the mean interest scores of students exposed to PAT and that of those exposed to TAT in Economics?
5. What are the mean interest scores of male and female students exposed to PAT in Economics?

6. What are the mean interest scores of male and female students exposed to TAT in Economics?

The following null hypotheses were tested at .05 alpha level in the present study:

1. The difference in the mean achievement scores of students exposed to PAT and that of those exposed to TAT in Economics is not significant

2. The difference in the mean achievement scores of male and female students exposed to PAT in Economics is not significant

3. The difference in the mean achievement scores of male and female students exposed to TAT in Economics is not significant

4. The difference in the mean interest scores of students exposed to PAT and those exposed to TAT in Economics is not significant

5. The difference in the mean interest scores of male and female students exposed to PAT in Economics is not significant

6. The difference in the mean interest scores of male and female students exposed to TAT in Economics is not significant

\section{METHOD}

The study adopted a quasi-experimental design to determine the effects of peer assessment technique (PAT) on secondary school students' achievement and interest in Economics.

The population of this study comprised 1,750 SS II students in twelve (12) secondary schools in Delta North Education Zone (Ministry of Education, Exams and Standard, Asaba). The sample of this study comprised 107 (49 males and 58 females) SSII students who offered Economics drawn from two coeducational secondary schools in Oshimili South Local Government Area, Delta North Education Zone of Delta State. Two co-educational secondary schools in the area were purposively selected for the study. Simple random sampling technique was used for the final selection of the respondents. 56 (26 males and 30 females) students were used for the experimental while 51 (23 males and 28 females) students constituted the control group. The instruments for data collection were Economics Achievement Test (EAT) and Economics Interest Inventory (EII). The EAT was a 60-item, 4 option multiple choice objective test on the theories of demand, supply and cost units of study in SSII Economics Curriculum. The EII was a 27 -item interest scale developed by the researchers. It has 4-point response scale. Copies of Economics Achievement Test (EAT) and Economics Interest Inventory (EII) were given to subject specialists and measurement and evaluation experts for face and content validation. Kuder Richardson formular 21 was used to determine the reliability coefficient of 0.95 for EAT whereas Cronbach Alpha was used to obtain a reliability coefficient of 0.81 for EII. 


\section{Experimental Procedure}

This study involved two groups of subjects: peer assessment group and teacher assessment group. The peer assessment group was experimental group while the teacher assessment group was the control group.

On the first day of the experiment, the test instrumentsEconomics Achievement Test (EAT) and Economics Interest Inventory (EII) were administered as pre-test to all the students in the sampled schools. The actual treatment sessions commenced after the pretest administration. It was conducted by the regular Economics teachers in the respective schools using the lesson plans prepared by the researcher for all the groups.

The experimental group was taught by their regular Economics teachers using the peer assessment procedure, i.e, the students' assessment of their peers at the end of every lesson.

For the control group, students were assessed by their regular classroom Economics teachers at the end of every lesson. This is the conventional technique of class assessment which served as a control strategy.

The researcher trained the Economics teachers as research assistants on the use of peer assessment procedure for the experimental group while the control group used conventional teaching method i.e teacher assessment technique. To ensure uniformity of the instruction, the teachers used the lesson plans prepared by the researcher for the all the groups. The treatment session lasted for eight weeks in which five (5) different assessments were conducted on various topics taught before the posttest. The peer assessment model in Sluijsmans (2002) was adopted for the experiment. The data collected were analyzed in line with the research questions and hypotheses. The EAT was awarded a total of 40 marks which implies that questions on the EAT was awarded 1 mark each. The decision rule for EII was pegged at a mean score of 2.50 for acceptance, reverse is the case if it is below 2.50 . Descriptive statistics - means and standard deviations were used to answer the research questions. Analysis of co-variance (ANCOVA) was used to test the null hypotheses at .05 alpha level. The decision rule for ANCOVA was that the null hypothesis was accepted if p-value is greater than 0.05 while it was rejected if reverse is the case (if p-value is less than or equal to 0.05 ).

\section{RESULTS}

Research Question 1: What are the mean achievement scores of students exposed to PAT and that of those exposed to TAT in Economics?
Table 1: Mean Achievement Scores of Students Exposed to PAT and that of those Exposed to TAT in Economics $(\mathrm{N}=107)$

\begin{tabular}{|c|c|c|c|c|}
\hline Group & $\mathrm{N}$ & Pre-test & Post-test & Mean \\
\hline & & $\mathbf{X}$ & $\mathbf{X}$ & Difference \\
\hline Experimental (PAT) & 56 & 21.71 & 20.68 & -1.03 \\
\hline Control (TAT) & 51 & 21.33 & 22.06 & 0.73 \\
\hline
\end{tabular}

The analysis on Table 1 shows the pre-test and post-test mean achievement scores of students exposed to PAT and TAT in Economics. The analyses further revealed that mean achievement score of students exposed to TAT is higher than that of the students exposed to PAT. However, it is a surprise that the pre-test score is higher than the post-test score in PAT which has a mean difference of -1.03 .

Research Question 2: What are the mean achievement scores of male and female students exposed to PAT in Economics?

Table 2: Mean Achievement Scores of Male and Female Students Exposed to PAT in Economics ( $\mathrm{N}=56)$

\begin{tabular}{|c|c|c|c|c|}
\hline $\begin{array}{c}\text { Experimental } \\
\text { Group (PAT) }\end{array}$ & $\mathrm{N}$ & $\begin{array}{c}\text { Pre-test } \\
\mathrm{X}\end{array}$ & $\begin{array}{c}\text { Post-test } \\
\mathrm{X}\end{array}$ & $\begin{array}{c}\text { Mean } \\
\text { Difference }\end{array}$ \\
\hline Male & 26 & 22.23 & 20.85 & -1.38 \\
\hline Female & 30 & 21.27 & 20.53 & -0.74 \\
\hline
\end{tabular}

Table 2 shows the pre-test and post-test mean achievement scores of male and female students exposed to PAT in Economics. Furthermore, the analyses revealed that mean achievement score of male students exposed to PAT is slightly higher than that of female students exposed to PAT. Then again, it is surprise that there is a reduction in the post-test scores when compared to pre-test scores which resulted in negative mean difference.

Research Question 3: What are the mean achievement scores of male and female students exposed to TAT in Economics?

Table 3: Mean Achievement Scores of Male and Female Students Exposed to TAT in Economics ( $\mathrm{N}=51)$

\begin{tabular}{|c|c|c|c|c|}
\hline $\begin{array}{c}\text { Control } \\
\text { Group } \\
\text { (TAT) }\end{array}$ & $\mathrm{N}$ & $\frac{\text { Pre-test }}{\mathrm{X}}$ & $\frac{\operatorname{Post-test}}{\mathrm{X}}$ & $\begin{array}{c}\text { Mean } \\
\text { Difference }\end{array}$ \\
\hline Male & 23 & 24.17 & 23.39 & -0.78 \\
\hline Female & 28 & 19.00 & 20.96 & 1.96 \\
\hline
\end{tabular}

The information on Table 3 shows the pre-test and post-test mean achievement scores of male and female students exposed to TAT in Economics. In addition, the analyses revealed that mean achievement scores of male students exposed to TAT is higher than that of their female counterparts exposed to TAT. However, it is unexpected that the pre-test score is higher than the post-test score for male students in TAT which has a mean difference of -0.78 .

Research Question 4: What are the mean interest scores of students exposed to PAT and that of those exposed to TAT in Economics? 
Table 4: Mean Interest Scores of Students Exposed to PAT and that of those Exposed to TAT in Economics ( $\mathrm{N}=107)$

\begin{tabular}{|c|c|c|c|c|}
\hline Group & $\mathrm{N}$ & $\frac{\text { Pre-test }}{\mathrm{x}}$ & $\frac{\text { Post-test }}{\mathrm{x}}$ & $\begin{array}{c}\text { Mean } \\
\text { Difference }\end{array}$ \\
\hline $\begin{array}{c}\text { Experimental } \\
\text { (PAT) }\end{array}$ & 56 & 39.80 & 40.68 & 0.88 \\
\hline Control (TAT) & 51 & 42.86 & 41.75 & -1.11 \\
\hline
\end{tabular}

The data analyzed on Table 4 show the pre-test and post-test mean interest scores of students exposed to PAT and TAT in Economics. Also, the analyses revealed that mean interest scores of students exposed to TAT is higher than that of their counterparts exposed to PAT.

Research Question 5: What are the mean interest scores of male and female students exposed to PAT in Economics?

Table 5: Mean Interest Scores of Male and Female Students Exposed to PAT in Economics $(\mathrm{N}=56)$

\begin{tabular}{|c|c|c|c|c|}
\hline $\begin{array}{c}\text { Experimental } \\
\text { Group } \\
\text { (PAT) }\end{array}$ & $\mathrm{N}$ & $\begin{array}{c}\text { Pre-test } \\
\mathrm{X}\end{array}$ & $\begin{array}{c}\text { Post-test } \\
\mathrm{X}\end{array}$ & $\begin{array}{c}\text { Mean } \\
\text { Difference }\end{array}$ \\
\hline Male & 26 & 38.15 & 37.50 & -0.65 \\
\hline Female & 30 & 41.23 & 43.43 & 2.20 \\
\hline
\end{tabular}

Analysis on Table 5 shows the pre-test and post-test mean interest scores of male and female students exposed to PAT in Economics. The analyses reveals further that mean interest scores of female students exposed to PAT is higher than the male students exposed to same test mode in Economics.

Research Question 6: What are the mean interest scores of male and female students exposed to TAT in Economics?

Table 6: Mean Interest Scores of Male and Female Students Exposed to PAT in Economics $(\mathrm{N}=51)$

\begin{tabular}{|c|c|c|c|c|}
\hline $\begin{array}{c}\text { Control } \\
\text { Group } \\
\text { (TAT) }\end{array}$ & $\mathrm{N}$ & $\frac{\text { Pre-test }}{\mathrm{x}}$ & $\frac{\text { Post-test }}{\mathrm{x}}$ & $\begin{array}{c}\text { Mean } \\
\text { Difference }\end{array}$ \\
\hline Male & 23 & 44.00 & 39.83 & -4.17 \\
\hline Female & 28 & 41.93 & 43.32 & 1.39 \\
\hline
\end{tabular}

Information presented on Table 6 shows the pre-test and posttest mean interest scores of male and female students exposed to TAT in Economics. In addition, the analyses reveal that mean interest scores of female students exposed to TAT is higher than their male counterparts exposed to same test mode in Economics.

Hypothesis 1: The difference in the mean achievement scores of students exposed to PAT and that of those exposed to TAT in Economics is not significant

Table 7: Tests of Between-Subjects Effects of Mean Achievement Scores of Students Exposed To PAT and that of those Exposed to TAT in Economics

\begin{tabular}{|c|c|c|c|c|c|}
\hline Source & $\begin{array}{c}\text { Sum of } \\
\text { Squares }\end{array}$ & Df & $\begin{array}{c}\text { Mean } \\
\text { Square }\end{array}$ & F & Sig. \\
\hline $\begin{array}{c}\text { Correcte } \\
\text { d Model }\end{array}$ & $759.512^{\mathrm{a}}$ & 4 & 189.878 & 15.870 & .000 \\
\hline $\begin{array}{c}\text { Intercep } \\
\mathrm{t}\end{array}$ & 413.517 & 1 & 413.517 & 34.562 & .000 \\
\hline
\end{tabular}

\begin{tabular}{|c|c|c|c|c|c|}
\hline Groups & 65.755 & 1 & 65.755 & 5.496 & .021 \\
\hline Gender & 2.038 & 1 & 2.038 & .170 & .681 \\
\hline Pretest & 632.918 & 1 & 632.918 & 52.900 & .000 \\
\hline Error & 1220.375 & $\begin{array}{c}10 \\
2\end{array}$ & 11.964 & & \\
\hline Total & 50691.000 & $\begin{array}{c}10 \\
7\end{array}$ & & & \\
\hline $\begin{array}{c}\text { Correcte } \\
\text { d Total }\end{array}$ & 1979.888 & $\begin{array}{c}10 \\
6\end{array}$ & & & \\
\hline
\end{tabular}

${ }^{*} p<0.05$

The analyses on Table 7 reveal that test mode effect on achievement is significant given that $\mathrm{F}_{(1,102)}=5.496$, and $\mathrm{p}<$ $0.05(.021<0.05)$. Therefore, the null hypothesis is rejected, thus, the difference in the mean achievement scores of students in PAT and TAT is significant. The students mean achievement score in TAT as could be seen from Table 2 is higher than that of those in PAT.

Hypothesis 2: The difference in the mean achievement scores of male and female students exposed to PAT in Economics is not significant

Table 8: Tests of Between-Subjects Effects of Mean Achievement Scores of Male and Female Students Exposed to PAT in Economics

\begin{tabular}{|c|c|c|c|c|c|}
\hline Source & $\begin{array}{c}\text { Sum of } \\
\text { Squares }\end{array}$ & Df & $\begin{array}{c}\text { Mean } \\
\text { Square }\end{array}$ & F & Sig. \\
\hline $\begin{array}{c}\text { Correcte } \\
\text { d Model }\end{array}$ & $\begin{array}{c}355.915 \\
\text { a }\end{array}$ & 2 & 177.957 & 15.156 & .000 \\
\hline Intercept & 150.720 & 1 & 150.720 & 12.837 & .001 \\
\hline Pretest & 354.552 & 1 & 354.552 & 30.196 & .000 \\
\hline Gender & .779 & 1 & .779 & .066 & .798 \\
\hline Error & 622.299 & 53 & 11.741 & & \\
\hline Total & $\begin{array}{c}24924.0 \\
00\end{array}$ & 56 & & & \\
\hline $\begin{array}{c}\text { Correcte } \\
\text { d Total }\end{array}$ & 978.214 & 55 & & & \\
$* p>0.05$ & & & & \\
\hline
\end{tabular}

Table 8 reveals that $\mathrm{F}_{(1,53)}=.066$, and $\mathrm{p}>0.05(.798>0.05)$, this implies that gender effect on achievement of those exposed to PAT is not significant. Therefore, the null hypothesis is not rejected, thus, the difference in the mean achievement scores of male and female students exposed to PAT is not significant.

Hypothesis 3: The difference in the mean achievement scores of male and female students exposed to TAT in Economics is not significant

Table 9: Test of Between Subject Effects of Mean Achievement Scores of Male and Female Students Exposed to TAT in Economics

\begin{tabular}{|c|c|c|c|c|c|}
\hline Source & $\begin{array}{c}\text { Sum of } \\
\text { Squares }\end{array}$ & $\begin{array}{c}\text { D } \\
\text { f }\end{array}$ & $\begin{array}{c}\text { Mean } \\
\text { Square }\end{array}$ & F & $\begin{array}{c}\text { Sig } \\
.\end{array}$ \\
\hline $\begin{array}{c}\text { Corrected } \\
\text { Model }\end{array}$ & $354.642^{\mathrm{a}}$ & 2 & 177.321 & 14.277 & $\begin{array}{c}.00 \\
0\end{array}$ \\
\hline Intercept & 271.720 & 1 & 271.720 & 21.877 & $\begin{array}{c}.00 \\
0\end{array}$ \\
\hline Pretest & .472 & 1 & .472 & .038 & $\begin{array}{c}.84 \\
6\end{array}$ \\
\hline Gender & 280.262 & 1 & 280.262 & 22.565 & $\begin{array}{c}.00 \\
0\end{array}$ \\
\hline
\end{tabular}




\begin{tabular}{|c|c|c|c|c|c|}
\hline Error & 596.181 & 48 & 12.420 & & \\
\hline Total & 25767.000 & 51 & & & \\
\hline $\begin{array}{c}\text { Corrected } \\
\text { Total }\end{array}$ & 950.824 & 50 & & & \\
\hline
\end{tabular}

$* p<0.05$

The result in Table 9 shows that $\mathrm{F}_{(1,48)}=22.565$, and $\mathrm{p}<0.05$ $(.000<0.05)$. This reveals that gender effect on achievement of those exposed to TAT is significant. Consequently, the null hypothesis is rejected which implies that the difference in the mean achievement scores of male and female students exposed to TAT is significant. The mean achievement score of male students is higher that of their female counterparts.

Hypothesis 4: The difference in the mean interest scores of students exposed to PAT and that of those exposed to TAT in Economics is not significant

Table 10: Test of Between Subject Effects of Mean Interest Scores of Students Exposed to PAT and that of those Exposed to TAT in Economics

\begin{tabular}{|c|c|c|c|c|c|}
\hline Source & $\begin{array}{c}\text { Sum of } \\
\text { Squares }\end{array}$ & Df & $\begin{array}{c}\text { Mean } \\
\text { Square }\end{array}$ & F & Sig. \\
\hline $\begin{array}{c}\text { Corrected } \\
\text { Model }\end{array}$ & $3011.906^{\mathrm{a}}$ & 4 & 752.977 & 10.959 & .000 \\
\hline Intercept & 4601.251 & 1 & 4601.251 & 66.967 & .000 \\
\hline Groups & 1.187 & 1 & 1.187 & .017 & .896 \\
\hline Gender & 538.790 & 1 & 538.790 & 7.842 & .006 \\
\hline Pretest2 & 2336.923 & 1 & 2336.923 & 34.012 & .000 \\
\hline Error & 7008.355 & 102 & 68.709 & & \\
\hline Total & $\begin{array}{c}191531.00 \\
0\end{array}$ & 107 & & & \\
\hline $\begin{array}{c}\text { Corrected } \\
\text { Total }\end{array}$ & 10020.262 & 106 & & & \\
\hline
\end{tabular}

$* p>0.05$

Results on Table 10 show that $\mathrm{F}_{(1,102)}=.017$, and $\mathrm{p}>0.05$ $(.896>0.05)$, this implies that test mode effect on mean interest scores of students in Economics is not significant. So, the null hypothesis is not rejected implying that the difference in the mean interest scores of students in PAT and TAT is not significant.

Hypothesis 5: The difference in the mean interest scores of male and female students exposed to PAT in Economics is not significant

Table 11: Test of Between Subject Effects of Mean Interest Scores of Male and Female Students Exposed to PAT in Economics

\begin{tabular}{|c|c|c|c|c|c|}
\hline Source & $\begin{array}{c}\text { Sum of } \\
\text { Squares }\end{array}$ & Df & $\begin{array}{c}\text { Mean } \\
\text { Square }\end{array}$ & F & Sig. \\
\hline $\begin{array}{c}\text { Corrected } \\
\text { Model }\end{array}$ & $2004.886^{\mathrm{a}}$ & 2 & 1002.443 & 14.591 & .000 \\
\hline Intercept & 3690.341 & 1 & 3690.341 & 53.713 & .000 \\
\hline Pretest2 & 1514.538 & 1 & 1514.538 & 22.044 & .000 \\
\hline Gender & 310.043 & 1 & 310.043 & 4.513 & .038 \\
\hline Error & 3641.329 & 53 & 68.704 & & \\
\hline Total & 98312.000 & 56 & & & \\
\hline $\begin{array}{c}\text { Corrected } \\
\text { Total }\end{array}$ & 5646.214 & 55 & & & \\
\hline
\end{tabular}

$* p<0.05$
Analyses of Table 11 show that $\mathrm{F}_{(1,53)}=4.513$, and $\mathrm{p}<0.05$ $(.038<0.05)$. This reveals that gender effect on mean interest scores of students exposed to PAT in Economics is significant. Thus, the null hypothesis is rejected which implies that the difference in the mean interest scores of male and female students exposed to PAT is significant. The female students are more interested than their male counterparts.

Hypothesis 6: The difference in the mean interest scores of male and female students exposed to TAT in Economics is not significant

Table 12: Test of Between Subject Effects of Mean Interest Scores of Male and Female Students Exposed to TAT in Economics

\begin{tabular}{|c|c|c|c|c|c|}
\hline Source & $\begin{array}{c}\text { Sum of } \\
\text { Squares }\end{array}$ & Df & $\begin{array}{c}\text { Mean } \\
\text { Square }\end{array}$ & F & $\begin{array}{c}\text { Si } \\
\text { g. }\end{array}$ \\
\hline $\begin{array}{c}\text { Correcte } \\
\text { d Model }\end{array}$ & $989.640^{\mathrm{a}}$ & 2 & 494.820 & 7.081 & $\begin{array}{c}.0 \\
02\end{array}$ \\
\hline Intercept & 1046.619 & 1 & 1046.619 & 14.978 & $\begin{array}{c}.0 \\
00\end{array}$ \\
\hline Pretest2 & 835.365 & 1 & 835.365 & 11.955 & $\begin{array}{c}.0 \\
01\end{array}$ \\
\hline Gender & 244.621 & 1 & 244.621 & 3.501 & $\begin{array}{c}.0 \\
67\end{array}$ \\
\hline Error & 3354.046 & 48 & 69.876 & & \\
\hline Total & $\begin{array}{c}93219.00 \\
0\end{array}$ & 51 & & & \\
\hline $\begin{array}{c}\text { Correcte } \\
\text { d Total }\end{array}$ & 4343.686 & 50 & & & \\
\hline$>$ D.05
\end{tabular}

$p>0.05$

The result of Table 12 shows that gender effect on mean interest scores of male and female students exposed to TAT in Economics is not significant given that $\mathrm{F}_{(1,48)}=3.501$, and $\mathrm{p}>$ $0.05(.067>0.05)$. Therefore, the null hypothesis is not rejected implying that the difference in the mean interest scores of male and female students exposed to TAT is not significant.

\section{DISCUSSION OF FINDINGS}

One of the findings of this study revealed that the mean achievement scores of students exposed to TAT is higher than that of those exposed to PAT and the difference in their mean achievement scores is significant. This result contradicts the findings of Asuai and Adeleye (2013); Saito (2008); Peterson and Irving (2008) that PAT was efficacious in enhancing students in Mathematics because students were able to learn from each other as they grade each other's work. This contradictions in the findings may have resulted from the sample size used in both studies.

Another finding of this study indicates that the mean achievement scores of male students exposed to PAT is slightly higher than that of female students exposed to PAT but the difference in their mean achievement scores is not significant. The findings also revealed that the mean achievement scores of male students exposed to TAT is higher than that of female students exposed to TAT and the difference in their mean achievement scores is significant. The findings agrees with the findings of Afuwape and Oludipe 
(2008) that there was no significant difference in academic performance in integrated science between males and females, and that for each year male students had higher mean scores than female students. In addition, Onuka (2007); Onuka and Oludipo (2006) found that the performance of students in the experimental group outweighed those from the control. The reason for the difference could be attributed to acquisition of knowledge in PAT which was infused in the teaching of Mathematics. The study also revealed that there was no significant difference in post-test mathematics performance of students in the two experimental groups due to their gender. In support of findings, Sprigler and Alsup (2003) carried out a study on gender achievement and found out that there was no gender difference on Mathematical reasoning ability at elementary level. Ding, Song and Richardson, (2007) was also in support of the view that there was no significant difference between male and female students in Mathematics. This can be attributed to the awareness of the importance of the subject by both sexes in the society and that one hardly survives without it. Additionally, Bassey, Joshua and Asim (2008) found that there is a significant difference between the Mathematics achievement of the rural male and female students. Ding, Song and Richardson (2007) were also in support of the view that there was no significant difference between male and female students in Mathematics.

Contradicting the above findings, Liu and Wang (2005) found that there was a significant effect for gender with female students having significantly higher perceived academic effort (academic self-concept subscale) than their male counterparts. Similarly, Ismail and Othma (2006) found that female students were found to have better results than their male counterparts and that gender played an important role in influencing success in the university. Opposite is the case of this finding made by Berkant (2009) that no significant difference was found between male and female students' meaningful causal thinking abilities. Lin and Overbaugh (2009) also found that, regardless of gender, two-thirds of the participants preferred asynchronous modes over synchronous ones. In addition, gender was weakly related to the participants' self-efficacy in both modes. Linear regression indicated that self-efficacy, in turn, was weakly related to academic performance.

Furthermore, the findings of this study revealed that students exposed to TAT have more interest than those exposed to PAT but the difference in their mean interest scores is not significant. This supports the findings of Cheng and Warren (2005) found that students had a less positive attitude towards assessing their peers in PAT. Conversely, this finding contradicts the finding of Peterson and Irving (2008) that the students had a positive view about PAT because it is a useful strategy for both students and teachers to assess themselves. After collecting and analyzing data through extensive interviews and classroom observations, the researchers found out that using PAT is a good technique for achieving academic success.
The findings revealed that female students exposed to PAT are more interested than the male students exposed to same test mode and a significant difference exists in their mean interest scores. Finally, the findings revealed that female students exposed to TAT are more interested than their male counterparts exposed to same test mode. However, no significant difference was shown in their mean interest scores. This supports the findings of Liu and Wang (2005) that there was a significant effect for gender with female students having significantly higher perceived academic effort (academic self-concept subscale) than their male counterparts. Additionally, Smith (2004) found that women consistently outperformed men in a Geography course even though they had started their coursers with almost identical A-level results. She also found that female students were more conscientious, less likely to miss lectures and more likely to believe that their marks reflected their ability than their male peers, that was because they felt that the good grades were their "insurance policy" for success. Moreover, the results of the study showed that female students were also more likely to seek and receive support from staff.

\section{CONCLUSION(S)}

The academic achievements and interest scores of secondary school students are not the same when assessed with PAT and TAT in Economics. The students' academic achievements and interest scores in Economics do not depend on gender or assessment mode. While emphasis should be on TAT, the use of PAT should be encouraged to involve students' participation in the assessment process and practice.

\section{Implication of the Study}

The implication of this study is that secondary school students' academic achievement assessed with TAT is higher than their counterparts assessed with PAT.

Secondary school students exposed to TAT showed more interest than those exposed to PAT even though the difference in their mean interest scores was not significant. This implies that interest of secondary school students are the same irrespective of assessment mode. The implication of this is that secondary school students' academic achievement is better in Economics when assessed with TAT which could also be extended to other secondary school subjects.

\section{RECOMMENDATIONS}

Based on the findings, the following recommendations were made;

1. Secondary school authorities should use only TAT for assessment of secondary school students' academic achievement in all secondary schools

2. School management authorities should motivate teachers by providing contemporary resource materials that enhance TAT in order to promote effective assessment process 
3. Secondary school authorities should ensure that teachers are provided with a conducive environment for use of TAT in secondary schools.

\section{REFERENCES}

[1] Anayochi, V., Anagara E., Anosike F. E., \& Asoluka C. U. (2010) The reliability coefficient and the validity indices of Mathematics questions papers set by NABTEB. (Unpublished project). Alvan Ikoku Federal College Education, Owerri.

[2] Andrade, H., \& Du, Y. (2005). Student perspectives on rubricreferenced assessment. Practical Assessment, Research and Evaluation, 10(3), 12-16.

[3] Anikweze, C. M. (2005, September). Assessment and the future of schooling and learning. A paper presented at the 31st Annual Conference of International Association for Educational Assessment, Abuja, Nigeria.

[4] Asuai, N. C., \& Adeleye, B. A. (2013). Impact of peer assessment on performance in mathematics among senior secondary school students in Delta State, Nigeria. Journal of Emerging Trends in Educational Research and Policy Studies (JETERAPS) 4(5), 719725

[5] Boud, D., \& Falchikov, N. (2006). Aligning assessment with longterm learning. Assessment and Evaluation in Higher Education, 31(4), 399-413.

[6] Cheng, W., \& Warren, M. (2005). Peer assessment of language proficiency.Language Testing, 22(1), 93-121.

[7] Chin, P (2016). Peer assessment.retrieved from (PDF) Peer assessment (researchgate.net)

[8] Edutopia (2014). What works in education. The George Lucas educational foundation. Retrieved from www.edutopia.org/assessment-guide-importance

[9] Eze, P. N. (2006). Effects of peer assessment technique on students academic achievement and in interest in French. Unpublished $\mathrm{Ph} . D$. Thesis. University of Nigeria Nsukka

[10] Falchikov, N. (2005). Improving assessment through student involvement:Practical solutions for aiding learning in higher and further education. London: Routledge

[11] Federal Republic of Nigeria (2004). National policy on education. (4th edition). Lagos: NERDC
[12] Federal Republic of Nigeria (2013). National policy on education. (5th edition). Lagos: NERDC

[13] Ghaicha A. (2016). Theoretical framework for educational assessment: A synoptic review. Journal of Education and Practice; 7(24); 212-231. Retrieved from: www.iiste.org

[14] Khadijeh M. (2010). Peer assessment: An alternative to traditional testing. MJAL 2(5), $396-405$..

[15] Khan, A. (2019). Meaning and types of assessment. Retrieved from: https://www.toppr.com/bytes/types-of-assessment/

[16] Nkwocha, P.C. (2004). Measurement and evaluation in the field of education.

[17] Owerri: Versatile Publishers.

[18] Papinczak, T., Young, L., \& Groves, M. (2007). Peer assessment in problem-based learning: A qualitative study. Advances in Health Sciences Education, 12(2), 169-186.

[19] Peterson, E. R., \& Irving, S. E. (2008). Secondary school students' conceptions of assessment and feedback. Learning and Instruction, 18(3), 238-250.

[20] Otubelu, D. O. (2008). Measurement \& evaluation for effective teacher performance. Onitsha: Ashantek Nigeria LTD.

[21] Ryan, G. J., Marshall, L. I., Porter, K., \& Jia, H. (2007). Peer, professor and self-evaluation of class participation. Active Learning in Higher Education,8(1), 49-61.

[22] Sadler, P. M., \& Eddie, G. (2006). The impact of self- and peergrading on student learning. Educational Assessment 11(1) 1-31.

[23] Schafer, W. D., Bene, G. N., \& Newbery, G. (2001). Effect of teacher knowledge of rubrics on students' advancement in four content areas. Applied Measurement in Education, 14(2), 151-170.

[24] Sebba, J., Deakin, C. R., Yu, G., Lawson, H., \& Harlen, W. (2008). Systematic review of research evidence of the impact on students in secondary schools of self and peer assessment. Report. In Research Evidence in Education Library. London: EPPICentre, Social Science Research Unit, Institute of Education.

[25] Sluijsmans, D. (2002). Student involvement in assessment: The training of peer assessment skills. Unpublished doctoral dissertation, Open University of the Netherlands, Heerlen.

[26] Yambi, T. (2018). Assessment and evaluation in education. Retrieved from: (99+) (PDF) ASSESSMENT AND EVALUATION IN EDUCATION $\mid$ Tomas Yambi Academia.edu 